\title{
The Potential Roles of Exosomes in Chronic Obstructive Pulmonary Disease
}

\author{
Nan Wang ${ }^{1 \dagger}$, Qin Wang ${ }^{2 \dagger}$, Tiantian Du $^{3}$, Abakundana Nsenga Ariston Gabriel ${ }^{3}$, Xue Wang ${ }^{4}$, \\ Li Sun ${ }^{1}$, Xiaomeng $\mathrm{Li}^{1}$, Kanghong $\mathrm{Xu}^{1}$, Xinquan Jiang ${ }^{1 *}$ and $\mathrm{Yi}_{\mathrm{Z}} \mathrm{Zhang}^{5 *}$ \\ ${ }^{1}$ School of Public Health, Shandong First Medical University and Shandong Academy of Medical Sciences, Taian, China, \\ ${ }^{2}$ Department of Anesthesiology, Qilu Hospital, Shandong University, Jinan, China, ${ }^{3}$ Department of Clinical Laboratory, \\ Cheeloo College of Medicine, The Second Hospital, Shandong University, Jinan, China, ${ }^{4}$ Department of Pharmacy, Binzhou \\ Medical University Hospital, Binzhou, China, ${ }^{5}$ Respiratory and Critical Care Medicine Department, Qilu Hospital, Shandong \\ University, Jinan, China
}

OPEN ACCESS

Edited by:

Mahmood Yaseen Hachim Mohammed Bin Rashid University of Medicine and Health Sciences, United Arab Emirates

Reviewed by:

Sarina Mueller, University of Erlangen Nuremberg, Germany Iman Mamdouh Talaat, University of Sharjah, United Arab Emirates

*Correspondence: Xinquan Jiang taianjxq@163.com Yi Zhang

cnzhang1@126.com

tThese authors have contributed equally to this work

Specialty section: This article was submitted to

Pulmonary Medicine,

a section of the journal

Frontiers in Medicine

Received: 17 October 2020 Accepted: 17 December 2020

Published: 14 January 2021

Citation:

Wang N, Wang Q, Du T, Gabriel ANA, Wang $X$, Sun L, Li X, Xu K, Jiang $X$ and Zhang $Y$ (2021) The Potential

Roles of Exosomes in Chronic Obstructive Pulmonary Disease.

Front. Med. 7:618506.

doi: 10.3389/fmed.2020.618506
Currently, chronic obstructive pulmonary disease (COPD) is one of the most common chronic lung diseases. Chronic obstructive pulmonary disease is characterized by progressive loss of lung function due to chronic inflammatory responses in the lungs caused by repeated exposure to harmful environmental stimuli. Chronic obstructive pulmonary disease is a persistent disease, with an estimated 384 million people worldwide living with COPD. It is listed as the third leading cause of death. Exosomes contain various components, such as lipids, microRNAs (miRNAs), long non-coding RNAs(IncRNAs), and proteins. They are essential mediators of intercellular communication and can regulate the biological properties of target cells. With the deepening of exosome research, it is found that exosomes are strictly related to the occurrence and development of COPD. Therefore, this review aims to highlight the unique role of immune-cell-derived exosomes in disease through complex interactions and their potentials as potential biomarkers new types of COPD.

Keywords: exosomes, COPD, immune cell, biomarker, treatment

\section{INTRODUCTION}

Chronic obstructive pulmonary disease (COPD) is a common chronic airway disease, characterized by irreversible, progressive airflow limitation, and repeated airway inflammation, which seriously affects the patient's breathing and interferes with the patient's life and work $(1,2)$. There are several viewpoints in COPD's pathogenesis, such as oxidative stress, epigenetics, cell aging, apoptosis, chronic inflammation, protease/antiprotease, and linear green body function (3). Environmental factors and genetic mutations play a role in it. Exposure to cigarette smoking(CS), whether active smoking or second-hand smoke, is the leading risk factor to get $\operatorname{COPD}(4,5)$. Environmental pollution and occupational chemical exposure in some developing countries, are essential factors causing COPD (6). Exposure to indoor air pollution can affect unborn babies and is a risk factor for chronic obstructive pulmonary disease. According to the World Health Organization (WHO), COPD is the third leading cause of death globally. Statistical projections state that by 2040 , the annual death toll will reach 4.4 million, and $90 \%$ of chronic obstructive pulmonary disease deaths will be more in both low-income and middle-income countries $(7,8)$. The airway epithelium CS events such as the first contact, long-term exposure to CS can induce epithelial cells to produce pro-inflammatory medium, senescence-associated secretory phenotype (MCP-1, IL-1, IL-6, IL-8), 
damage-associated molecular patterns (receptor for advanced glycation end-products, heat shock proteins, S100 proteins, highmobility group box), the media which is released into the pulmonary and systemic circulation $(9,10)$, can stimulate the damage to the lung parenchyma, alveolar damage, and promote the development of COPD (11). Current treatment methods for COPD can only slow down the loss of lung function and cannot reverse the deterioration of lung structure and function. Therefore, it is essential to understand the molecular mechanism of COPD's occurrence and development and optimize the clinical treatment strategy. Various studies support the fact that exosomes containing miRNA, lncRNA, and proteins that are involved in the pathogenesis of $\operatorname{COPD}(12,13)$, many exosomes, including miR-101, miR-223, miR-144, and miR$1274 \mathrm{a}$ act by influencing the molecular pathways associated with the pathogenesis of COPD which includes Kras, Notch, Smad, and TGF- $\beta$ (14). Besides, these molecules are potential candidates for the early diagnosis and treatment of COPD. There are much-emerging shreds of evidence reporting that increased or decreased exosomes' expressions are a common feature of various lung diseases, including COPD (15). Takahashi et al. reported that changes in exosome numbers could predict a patient's physiological outcomes. For example, exosomes derived from bronchial endothelial cells were increased significantly in stable COPD (SCOPD), which were also increased in acute exacerbation COPD (AECOPD) (16).

Exosomes can maintain the stability of the intracellular environment (17). However, they can also get involved in different functions of the recipient cells (18). Direct exposure to a harmful stimulus (e.g., CS, air pollutants, and infection) may affect the nucleic acid load of lung-derived exosomes and participate in the progress of lung diseases (19). It was also found that exosomes may cause COPD pathological disturbances, that include chronic inflammation, oxidative stress, multiple organ dysfunction, epigenetic changes, cell apoptosis, aging, and diseases related to linear green body dysfunction $(20,21)$, and

\footnotetext{
Abbreviations: AECOPD, acute exacerbation chronic obstructive pulmonary disease; AlAT, alpha one anti-trypsin; Alix, ALG-2 interacting protein X; AM, alveolar macrophages; BALF, bronchial lavage fluid; CAMP, cyclic adenosine monophosphate; CCN1, protein cysteine-rich angiogenic protein 61; CCR10, chemokine receptor 10; COPD, chronic obstructive pulmonary disease; COX2, cyclooxygenase-2; CS, cigarette smoking; CSE, cigarette smoke extract; DC, dendritic cells; ECM, extracellular matrix; EMT, epithelial-mesenchymal transition; FAIM, Fas apoptosis inhibitory molecule Hsp70: heat shock $70 \mathrm{kDa}$ protein 4; FEV1, forced expiratory volume in $1 \mathrm{~s}$; FEV1/FVC, forced expiratory volume in $1 \mathrm{~s}$ /forced vital capacity; FFMI, fat-free body mass index; HBECs, human bronchial epithelial cells; HPMECs, human pulmonary microvascular endothelial cells; HRV, human rhinovirus; ICSs, Inhalation corticosteroids; IncRNA, long non-coding RNA; MAP3K, mitogen-activated protein kinase kinase kinase; MC, mast cells; miRNA, microRNA; MMP, matrix metalloproteinase protein; MVB, multivesicular bodies; $\mathrm{M} \phi$, macrophages; NE, neutrophilic elastase; NK:17, natural killer cells; NTHI, non-typeable Hemophilus influenza; NOR, neuron-derived orphan receptor; PASMCs, pulmonary artery smooth muscle cells; SCOPD, stable chronic obstructive pulmonary disease; SOCS, suppressor of cytokine signaling; siRNA, Small interfering RNA; STAT, signal transducer and activator of transcription; TGF- $\beta$, transforming growth factor $\beta$; TNFR2, tumor necrosis factor receptor 2; Trop, Trophoblast cells surface antigen; Tsg101, tumor susceptibility gene 101; TUG1, taurine-upregulated gene 1; UCHL1, ubiquitin C-terminal hydrolase; WHO, World Health Organization.
}

this proves that exosomes may act as a promising biomarker for the diagnosis of COPD (14). This is because, during the progression of COPD disease, COPD patients will produce a large number of exosomes, and can be isolated from sputum (22), plasma $(23,24)$, bronchial lavage fluid (BALF) (25), which suggests that exosomes considered as potential non-invasive diagnostic tools for COPD. This review first introduces the biological characteristics and functions of exosomes, introduces the role of exosomes in mediating intercellular communication and regulating immune cells in COPD, and finally clarifies the recent progress of exosomes in auxiliary clinical diagnosis and treatment of COPD.

\section{MAIN COMPONENTS OF EXOSOMES Biological Characteristics of Exosomes}

Exosomes are membrane vesicles with a bilayer lipid of about $30-150 \mathrm{~nm}$ in diameter, produced by early and late endosomes, and eventually, form multivesicular bodies (MVB) (26). A variety of cells releases these vesicles, such as structure cells (epithelial cells, endothelial cells, and alveolar I and II, alveolar macrophages, fibroblasts), and immune cells (B and T lymphocytes, macrophages, dendritic cells) (3). CD9, CD63, CD81, and CD82 proteins from the peripheral membrane are fused during release into the extracellular space. These proteins are considered markers of exosomes (27). Besides, endosome markers also include heat shock $70 \mathrm{kDa}$ protein 4 (Hsp70), MHC classes I and II, ALG-2 interacting protein X (Alix), and tumor susceptibility gene 101 (Tsg101) $(28,29)$.

\section{The Genetic Material in Exosomes}

The main components of exosomes are protein and lipid, genetic material including DNA, mRNA, miRNA, lncRNA, and metabolites $(30,31)$. Among them, miRNA is a highly studied regulatory molecule. It has found that a small non-coding RNA between 19 and 25 nucleotides in length together with silencing the $3^{\prime}$-untranslated region ( $\left.3^{\prime} \mathrm{UTR}\right)$ of the target mRNA, negatively regulates its expression at the transcriptional and post-transcriptional levels, which in return affects various cellular functions such as proliferation, apoptosis, differentiation, and emergency resistance. The events mentioned above also affect biological processes that include autophagy, inflammatory response, cellular senescence, tissue remodeling, immune regulation, and angiogenesis $(32,33)$. These processes usually involve the level of multiple genes. Besides, the length of the lncRNA is over 200 nucleotides, and located in the nucleus, transcripted by RNA polymerase II, but cannot make reaction with proteins; lncRNA has been shown to participate in mRNA splicing after transcription and protein translation process, usually expresses the tissue specificity and cell specificity, and in the maintenance of steady-state (34). More information about these two types of RNA is summarized in Table $\mathbf{1}$.

\section{Biological Functions of Exosomes}

Exosomes can transmit information to target cells in three ways: (1) Interact with the cell surface through receptors; (2) Endocytosis; (3) The direct fusion of outer cell membrane and 
plasma membrane as it is shown in Figure 1. Briefly, exosomes' primary function is to transport essential substances and mediate communication between cells (35). This biological effect unit regulates the properties of target cells $(36,37)$. More evidence shows that exosomes are involved in different respiratory diseases, including COPD (38). In airway physiology, exosomes from alveolar macrophages, epithelial cells, and endothelial cells affect the disease's progress in controlling the stability of the intracellular environment and changing the function of

TABLE 1 | miRNA vs. IncRNA.

\begin{tabular}{lll}
\hline & miRNA & IncRNA \\
\hline Source & Pri-miRNA & Multiple sources \\
Length & $19-25 \mathrm{nt}$ & $>200 \mathrm{nt}$ \\
Protein coding & no & no \\
Regulatory target & mRNA 3'UTR & Proteins, RNAs, and DNAs \\
Effect & Up-regulate or downregulate & Up-regulate or \\
& mRNA & downregulate target \\
Mechanisms & Inhibits gene expression at the & Maintain the dynamic \\
& transcriptional and & balance of cells and tissues \\
& post-transcriptional levels & and regulate inflammation \\
\hline
\end{tabular}

miRNA, microRNA; InCRNA, long non-coding RNAs. receptor cells (39). Under normal circumstances, exosomes are highly stable in biological fluids due to the bilayer protection of lipids. High-throughput sequencing technology can detect highly sensitive and highly specific exosomes. A large amount of exosome secretion can be detected in various biological fluids, such as sputum, blood, BALF, urine, pleural effusion, ascites, synovial fluid, and breast milk (40). This makes exosomes potentially valuable for the diagnosis, prognosis, and treatment of respiratory diseases.

\section{THE CLINICALLY RELEVANT ROLES OF EXOSOMES IN COPD}

Chronic obstructive pulmonary disease is a chronic inflammatory respiratory disease characterized by irreversible airflow limitations caused by prolonged exposure to cigarette smoke or harmful irritants. Multiple studies have demonstrated that exosomes play an essential role in the occurrence and progression of COPD, including inflammation of the lung parenchyma and surrounding small airways (chronic bronchitis), degeneration of lung tissue (emphysema), and remodeling of small airways, leading to decreased lung function (41). The related exosomes miRNAs and IncRNAs involved in COPD's development and progression are summarized in Figure 2.

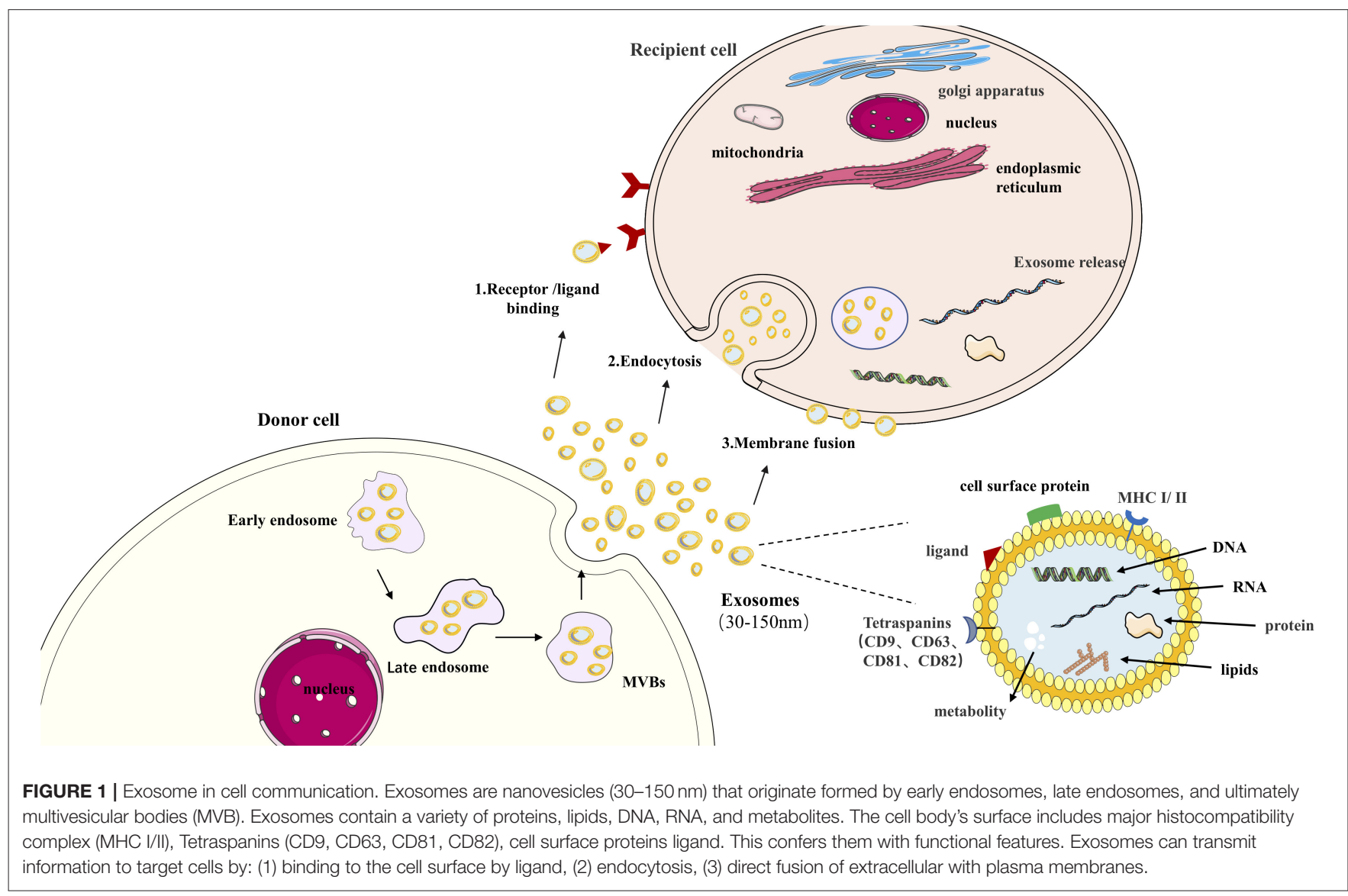




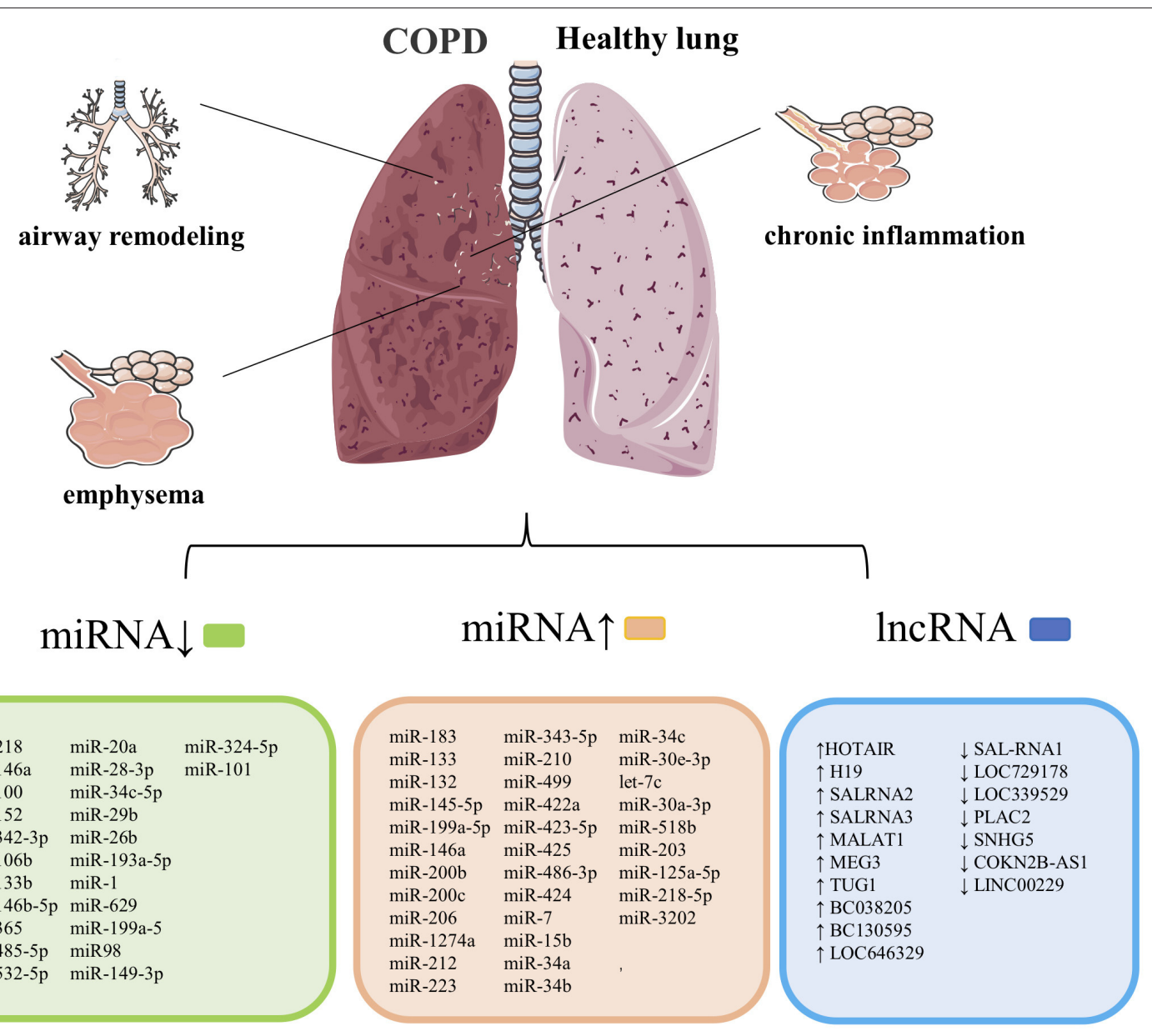

FIGURE 2 | COPD's pathological features are chronic inflammation of the lung parenchyma and surrounding airways, emphysema, and narrowing. Remodeling of the small airways, and exosomes are closely related to the course of this cases. List of previously reported miRNA associated with COPD. COPD, chronic obstructive pulmonary disease. Summary data are based on the following references $(4,14,15,42-52)$ for miRNAs and (53-56) for IncRNAs.

\section{The Role of Exosomes in the Pathogenesis of COPD}

\section{Exosomes and Chronic Airway Inflammation}

Cordazzo et al. reported that cigarette smoke extract (CSE) could induce exosomes to be released from mononuclear cells, induce bronchial epithelial cells to produce IL8, monocyte chemoattractant protein-1, and up-regulate CD542, thereby promoting inflammation (57). Also, Tan et al. believe that inflammation and exosomes increase in patients with COPD Relevant, they used Exo ELISA kits to compare the levels of $\mathrm{CD}^{+}$exosomes in COPD patients and healthy controls, and found that the levels of COPD patients were significantly higher (58). Moon et al. believe that exosomes rich in COPDrelated protein cysteine-rich angiogenic protein 61 (CCN1) can be cleaved after CS exposure. CCN1 allows inflammatory signaling to the far end of the lung. Interaction with integrin 7 in pulmonary epithelial cells activates the secretion of matrix metalloproteinase protein (MMP-1) in pulmonary epithelial cells, thereby promoting the release of vascular endothelial growth factor and IL-8.Il-8 promotes neutrophil infiltration into the lung parenchyma and causes inflammation (59). Besides, after CSE treatment, MEG3 up-regulated in $16 \mathrm{HBE}$ cells of COPD patients can release the expressions of inflammatory factors IL1, IL6, and TNF by regulating HSA-Mir-218, thus inducing inflammation and cell apoptosis.

\section{Exosomes and Emphysema}

Emphysema is characterized by decreased airway elasticity, hyperinflation, and swelling of the terminal bronchioles (60). Ezzie et al. believe that transforming growth factor $\beta$ (TGF$\beta$ ) suggested changes in miRNA expression, such as miR-223 and miR-15b. After knocking out the transforming growth factor TGF R-II in mouse lung epithelial cells, they showed emphysema signs (14). Van Pottelberge et al. analyzed miRNA expression in sputum samples from 32 subjects using qPCR. The results showed that the expression of miR-125b and let7C in PATIENTS with COPD was lower than that in healthy non-smokers. Low let-7C expression was negatively correlated with the concentration of tumor necrosis factor receptor 2(TNFR2) (42). 
TABLE 2 | List of miRNAs potentially associated with COPD pathogenesis.

\begin{tabular}{|c|c|c|c|c|}
\hline miRNA & Expression & Target & Function/pathogenesis & References \\
\hline miR-210 & $\uparrow$ & ATG7 & $\begin{array}{l}\text { Promoted myofibroblast differentiation in primary lung } \\
\text { fibroblasts control autophagy }\end{array}$ & (63) \\
\hline miR-144 & $\uparrow$ & CFTR, IRF7 & Regulate inflammatory and antiviral responses in COPD & $(43)$ \\
\hline miR-101 & $\uparrow$ & CFTR, MKP1 & & \\
\hline miR-223 & $\uparrow$ & TGF- $\beta$ & TGF- $\beta$ signal activation is associated with emphysema & $(14)$ \\
\hline $\operatorname{miR}-15 b$ & $\uparrow$ & SMAD7 & TGF- $\beta$ inhibitory primary intracellular signal smad2/3/4 & $(14)$ \\
\hline miR-218 & $\downarrow$ & $N F-\kappa B$ & $\begin{array}{l}\text { Up-regulates the expression of several pro-inflammatory } \\
\text { cytokines by AEC, including IL- } 6 \text { and CXCL8. }\end{array}$ & $(65)$ \\
\hline miR-128-5p & $\downarrow$ & apoptotic processes & Participate in the epithelial damage and remodeling in COPD & $(44)$ \\
\hline miR-181d & $\uparrow$ & $\begin{array}{l}\text { and growth factor } \\
\text { pathways }\end{array}$ & & $(43)$ \\
\hline $\operatorname{miR}-1274 a$ & $\uparrow$ & $\mathrm{FOXO} 4$ & Probably related to oxidative stress or cellular aging in COPD & $(14)$ \\
\hline miR-1 & $\downarrow$ & AKT & COPD-associated skeletal muscle dysfunction & $(66)$ \\
\hline miR-542-5p & $\uparrow$ & - & & $(45)$ \\
\hline miR-542-3p & & & & \\
\hline
\end{tabular}

$\uparrow$ Upregulation; $\downarrow$ downregulation.

Furthermore, Stockley and Turne reported that glycoproteins alpha one anti-trypsin (A1AT) works by inhibiting the process of preventing excessive inflammation neutrophils and eosinophil enzymes work, and A1AT deficiency will lead to the development of emphysema (61). It was also found that in the evaluation of miRNA expression in lung tissue of patients with COPD patients with mild and moderate emphysema, moderate five miRNAs in lung samples of emphysema patients were significantly down-regulated, namely miR-34c, miR34b, miR-149, miR-133a, and miR-133b. Among them, the expression of miR-34c was significantly down-regulated (62).

\section{Exosomes and Airway Remodeling}

Long-term harmful stimuli lead to damage to airway epithelial cells, promote phenotypic changes of epithelial cells, and lead to fibrosis and airway remodeling. Fujita's research showed that CS-induced down-regulation of miR-210 could drive the differentiation of myofibroblasts in airway remodeling and inhibit the expression of ATG7 in LFS to control the autophagy process directly (63). This indicates that exosomes may contribute to the tracking of COPD differentiated fibers. miR-15b may be involved in airway remodeling by mediating TGF- related signaling pathways (15). Besides, it has also revealed that different microRNAs such as miR-224, miR-339$5 \mathrm{p}$, and miR-382 are involved in COPD's pathogenesis (64), and particular pieces of information are presented in Table 2.

Gu's research shows that taurine-upregulated gene 1 (TUG1) expression is enhanced in COPD patients, and TUG1 inhibits the expression of miR-145-5pp/DUSP6 axis to promote airway remodelings such as TGF- $\beta 1$, mucus hypersecretion, collagen 1 and $\alpha$-SMA and inflammation such as increased IL- 6 and pulmonary neutrophil infiltration (67). TUG1, combined with CDKN2B-AS1, can be used to predict acute exacerbation in COPD patients (68). It was found that the expressions of SAL-RNA2 and SAL-RNA3 (senescence-related genes) were significantly increased in COPD lung tissues, and the expressions of p53 and P21 were up-regulated. This shows that lncRNA in airway epithelial cells II type error control in the process of aging may be involved in the pathogenesis of COPD (53). In summary, exosomes influence COPD's occurrence and development by regulating inflammatory, emphysema, airway remodeling, and pulmonary fibrosis. MiRNAs and lncRNAs involved in the development of COPD are summarized in Figure 2.

\section{Immune Cell-Derived Exosome Participate in COPD}

Exosomes are recognized as tools for mediating intercellular communication and signal transduction and signaling to immune cells to regulate function. Various studies highlighted that exosomes are secreted by some types of cells, including immune cells, such as B lymphocytes (69), T lymphocytes (70), macrophages (M申) (71), mast cells (MC) (30), dendritic cells (DC) (72), and 17 natural killer cells (NK) (73). Immune-cell-derived exosomes perform numerous physiological and pathological functions, including antigen presentation, immunosuppression, T-cell polarization toward Treg cells, and anti-inflammatory effects, to enhance or suppress immune activity (74). Infiltration of various immune cells, such as neutrophils and macrophages, into small airways, is a common phenomenon in COPD (75). For these reasons, in-depth research is needed to explore the role of immune-cell-derived exosomes in COPD.

\section{Role of Macrophages and Exosomes in COPD}

Alveolar macrophages (AM) form the first host defense line against infection/inhalation of harmful substances. They are one of the primary cells in the lung that produce exosomes (76). AM promotes inflammation of COPD. First, macrophagederived exosomes induce differentiation of immature monocytes into macrophages by mediating miR-223 (77). Exosomes miR17 and miR-221 then promote macrophage migration by mediating integrin $\beta$ under sterility stimulation (78). Finally, 


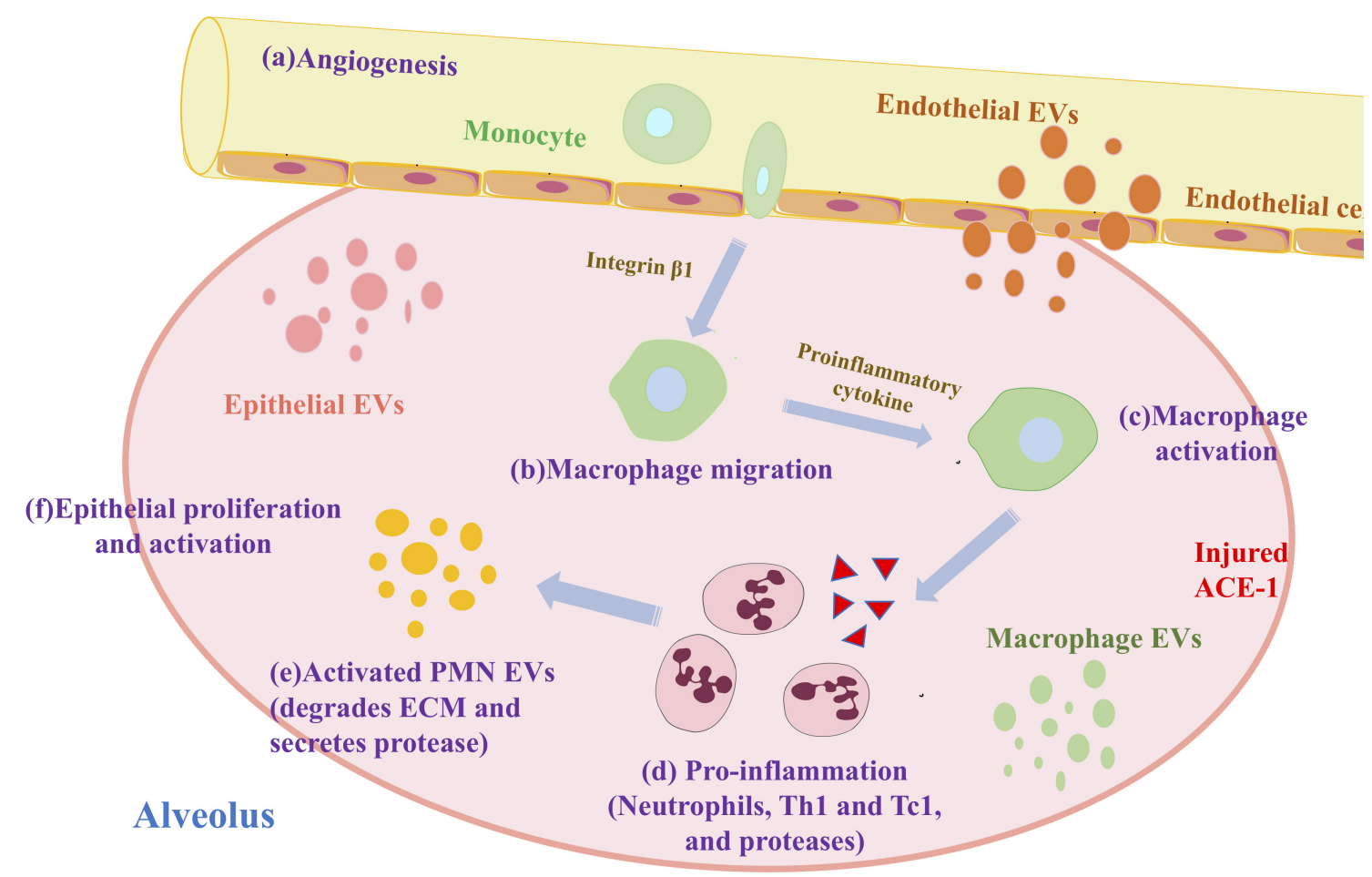

FIGURE 3 | Exosomes and macrophages promote alveolar inflammation in COPD.

exosomes miR-221 and miR-320 stimulate the secretion of proinflammatory cytokines, thereby activating AM (79). After a series of differentiation, migration, and activation, AM recruits neutrophils, Th1, and Tc1, to promote inflammation (32). The specific process is shown in Figure 3.

After CS stimulation, miRNA mediated by endothelial cells, such as miR-125a, miR-126, miR-191, were transferred to macrophages to promote apoptotic cell clearance (80). A study reported that macrophages release outside secretes body with antigen-presenting ability lower associated macrophage transfer specific immune (81). Kulshreshtha et al. found that epithelialderived exosomes extracted from BALF of mice with COPD induced undifferentiated macrophages and proliferative effects (82). During the pathogenesis of COPD, alveolar macrophages combine with suppressor of cytokine signaling (SOCS) protein, which is taken up by alveolar epithelial cells and inhibits IFN $\gamma$-induced signal transducer and activator of transcription (STAT) (58). Also, M1 macrophages (pro-inflammatory) are the predominant cells in the peripheral blood of COPD patients, leading to pro-inflammatory factors (IL-1 $\beta$, IL-12, TNF- $\alpha$ ) and lncRNA miR-155HG are up-regulated (83). As mentioned above, the studies show that the increase of exosomes in the regulation of lung inflammation by macrophages in the lung has practical significance.

\section{Role of Neutrophils and Exosomes in COPD}

Neutrophils are a crucial component of innate immune responses in COPD, and Kristopher described a new pathogen, activated
PMN (neutrophil) source of NE-rich exosomes (84). These exosomes bind and degrade the extracellular matrix (ECM) involved in COPD's pathogenesis. Mac-1 and neutrophilic elastase (NE) play essential roles in this process. NE is the surface binding protease obtained by $\mathrm{CD}^{+} / \mathrm{CD}^{+} 6 \mathrm{~b}^{+}$nanovesicles during PMN degranulation, and $\mathrm{NE}$ is resistant to A1AT. It is because of the resistance of the A1AT. The ECM targeting, the outer body of the outer body, which is more potent than the free NE biology (85), and an imbalance of the proteinaseantiprotease system are typical in COPD (86). In this system, PMN-derived NE and lung suppressor A1AT are most prominent (87). Experiments have shown that injecting enough NE into an animal's airways can cause emphysema (88). These findings show that novel exosomes derived from neutrophils participate in disease progression by breaking ECM dynamic balance through NE activity in COPD.

\section{Role of Other Cells and Exosomes in COPD}

Among mast cells, the exosomes of human mast cell line-1 overlapped with the proteins of the exosomes inhaled by the patient, suggesting that mast cells also contribute to the lung exosome pool (89). It is worth noting that exosomes from NK cells can react against NK cells and increase the cytotoxic activity and NK cells' targeting (90). Besides, exosomes released by macrophages, NK cells, and dendritic cells through a paracrine act as pro-inflammatory mediators of the innate immune system (81). Exosomes secreted by DC are associated with amplification of the immune response, and DC-based exosomes induce 
specific humoral responses and activation of $\mathrm{CD} 4^{+} \mathrm{T}$ cells and $\mathrm{CD}^{+} \mathrm{T}$ cells (91). As mentioned above, immune cell-derived exosomes are involved in the development and progression of COPD. Exosomes derived from circulating immune cells have immunomodulatory effects. Therefore, it has been reported that immune-cell-derived exosomes can be delivered to target cells by small molecule drugs or specific molecules to stimulate the immune system in patients to recognize and destroy lesions (90). Also, exosomes derived from circulating immune cells can serve as specific biomarkers for the severity of inflammation, which has been demonstrated in liver inflammation $(92,93)$. The application of exosomes derived from immune cells in immunotherapy is now considered a promising tool in COPD treatment. In conclusion, there are still many questions to be answered about the relationship between immune cells and exosomes involved in lung inflammation and injury in COPD.

\section{CLINICAL APPLICATION OF EXOSOMES IN COPD}

\section{Exosomes as Potential Biomarkers for the Clinical Diagnosis of COPD}

The study results compared healthy exosomes and exosomes released by bronchial epithelial cells in COPD patients, especially in the AECOPD, and the study reported that exosomes from AECOPD were significantly increased. Moreover, they found that by detecting exosomes' content, pulmonary endothelial cell apoptosis can be analyzed. The degree of activation and the dysfunction of endothelial cells is directly related to the severity of COPD. It is usually evaluated by forced expiratory volume in $1 \mathrm{~s}$ (FEV1) to track the disease's advancement (16). Lacedonia and his research team reported that the number of exosomes in sputum is negatively correlated with FEV1, similar to changes in exosome levels related to inflammation. It shows that senescent cells accumulated with age in COPD may affect the release and competition of circulating exosomes (94). Moreover, Shi et al. reported that miR-203 might be a new biomarker for COPD diagnosis; it is just because miR-203 targets P13KCA to inhibit nuclear factors light chain enhancers, which activate B cell signaling pathways significantly involved in COPD (95). Another critical study showed that evidence suggests that miR21 has potential value in the diagnosis and treatment of COPD. The level of miR-21 in the serum of smokers and patients with COPD is significantly increased. The increased level of miR-21 is associated with the percentage of forced expiratory volume in 1 s/forced vital capacity (FEV1/FVC) (18).

Besides, comparing miR-4455 and miR-4785 in smokers and non-smokers in COPD patients, there was a significant expression difference (96). This made the two exosomal microRNAs to be considered as a potential biomarker for early diagnosis of COPD. Chronic obstructive pulmonary disease, early diagnosis, and patient monitoring are other essential factors. Based on that, researchers conducted a study. They found that miR-218-5p is another essential miRNA that plays an essential role in COPD pathogenesis and promises to be a successful candidate for diagnosing and controlling COPD patients (65). Moreover, other essential study findings showed that miR-29c and miR-126 were up-regulated in Stage III COPD patients relative to stable controls. Such results indicate that all these miRNAs may be used as screening biomarkers for COPD patients (97). As mentioned above from different studies, the findings show that exosomal miRNAs can be used as potential biomarkers for the diagnosis of COPD.

\section{Application of Exosomes in COPD Prognosis}

Studies have shown that exosomes with CD144, CD31, and CD62E are more abundant in patients with AECOPD than in patients with SCOPD, suggesting that COPD patients tend to deteriorate can be used as an indicator of prognosis (16). Ge et al. detected the expression of ANRIL in SCOPD patients, AECOPD, and the whole group. They found that the expression of ANRIL in AECOPD patients was the lowest. The expression of ANRIL in SCOPD patients was not related to the GOLD stage. In contrast, the expression of ANRIL in patients with AECOPD was negatively correlated with the GOLD stage. Most importantly, ANRIL expression in patients with AECOPD and stable COPD is negatively correlated with inflammatory cytokines such as IL1B, IL17A, TNF, and LTB4 (98). They finally concluded that lncRNA ANRIL (antisense non-coding RNA at INK4 locus) is associated with chronic diseases' occurrence and prognosis.

It is well-known that skeletal muscle weakness is a severe systemic complication of COPD, which seriously affects patients' quality of life and mobility. Lewis et al. showed that exosome miR-1 plays a crucial role in skeletal muscle dysfunction in patients with COPD, associated with smoking history, function, defatted body mass index, 6-min walking distance, and percentage of quadriceps type I muscle fibers (66). Besides, compared with healthy COPD patients with fat-free body mass index (FFMI), H19 is expressed by demethylation isolation of has-miR-519a after up-regulation increases patients' susceptibility with COPD to low FFMI (99). So far, researchers have used exosomes as a potential non-invasive biomarker for COPD that has never stopped. In short, these studies are mainly used to identify the role of exosomes in the diagnosis of COPD, providing a new basis for the early clinical diagnosis of some exosomes in COPD. Through continuous efforts, new diagnostic tools and more complete treatment methods may appear.

\section{Exosomes Are Essential in the Treatment of COPD COPD Treatment Using Exosomal miRNA}

At present, the drugs used to treat COPD are mainly bronchodilators, which are borrowed from medications used to treat asthma. Inhalation corticosteroids (ICSs) are added to LAMA/LABA combination therapy (triple therapy), and the risk of exacerbation and death in COPD patients. However, most patients are not sensitive to steroids, and the use of large doses increases the risk of pneumonia (100). Therefore, COPD patients urgently need critical target treatment. There is also a great need 
for drugs to prevent the aggravation of the disease and pulmonary hypertension, plus many other COPD complications.

Sun's study reported that miR-206 expression in human pulmonary microvascular endothelial cells (HPMECs) exposed to CS was up-regulated. They also noted that both Caspase3 and HPMEC apoptosis activities were increased. There was a negative correlation between the expression levels of miR-206 and Notch3 and VEGFA mRNA levels. During their study, they concluded that miR-206 could directly target Notch3 and VEGFA to regulate the process of COPD vascular remodeling (101). It was reported that anti-miR-27-3p could effectively reverse the inflammatory process and reduce the infiltration of neutrophils and macrophages in the lungs and the level of inflammatory cytokines in BALF. Another study aimed to determine miRNA3202 in COPD noted that the overexpression of miR-3202 could significantly inhibit the increase of $\mathrm{T}$ lymphocyte IFN$\gamma$ and TNF- $\alpha$ levels induced by CSE while increasing the expression of Fas and FasL. The study also revealed that the high levels of miR-3202 pass target gene Fas apoptosis inhibitory molecule (FAIM) 2 to inhibit T cell apoptosis and protect human bronchial epithelial cells (HBECs). FAIM2 plays a central role in COPD's pathogenesis, inhibits $\mathrm{T}$ cell death, and participates in CS-induced cell apoptosis and cell wall destruction (64). Besides, it has also been found that the high levels of miR145-5p alleviate CS-induced apoptosis and the production of pro-inflammatory cytokines by inhibiting the lytic expression of p53 and caspase339. Besides, some miR-145-5p and KLF5 inhibits CSE-induced NF- $\kappa$ B signal activation, thereby reducing participation in the pathogenesis of COPD (102).
$\mathrm{Du}$ et al. tested the expression rates of miR-181c in $34 \mathrm{COPD}$ (smoking cases) patients relative to safety controls, and findings showed that miR-181c might be slightly less controlled in COPD patients than healthy control patients had never smoked. They also demonstrated that the upregulation of miR-181c might be correlated with several consequences, such as inflammatory response reduction, neutrophil invasion, reactive oxygen species formation, and inflammatory cytokine development. MiR-181c downregulation may be correlated with different consequences. They also found that miR-181c exerts its impact by attacking CCN1. The downregulation of the miR-181c could contribute to the increase in CCN1 expression in the pulmonary tissues of patients with COPD relative to stable controls. The results mentioned above show that miR-181c might be used as a therapeutic target to treat COPD patients (103). Another study also reported that the deregulation of miR-126 is correlated with ATM kinase activation, and they have also demonstrated that miR-126 levels have been decreased in the smoker and COPD endothelial blood cells relative to non-smoker subjects. These findings indicated that the reduction of miR-126 through ATM targeting might facilitate tissue aging and dysfunction in smokers and COPD subjects. This miRNA may also be seen as a new therapeutic target for treating COPD patients (104). Taken together, it is clear that exosomes play an essential role in the treatment of COPD patients.

\section{The Treatment of COPD by Synthetic siRNA}

Synthetic siRNAs' potential to treat COPD by transcriptionally down-regulating target genes' expression has been successfully

TABLE 3 | Principle, advantages and disadvantages of common exosome isolation methods.

\begin{tabular}{|c|c|c|c|c|}
\hline Methods & Theory & Advantages & Disadvantages & References \\
\hline $\begin{array}{l}\text { Ultracentrifugation } \\
\text { techniques (UC) }\end{array}$ & $\begin{array}{l}\text { The required components are obtained } \\
\text { according to the size and density } \\
\text { differences of each component in the } \\
\text { sample. }\end{array}$ & $\begin{array}{l}\text { There is no need to mark the outer cut } \\
\text { body to avoid cross contamination }\end{array}$ & $\begin{array}{l}\text { High cost, Time consuming, structural } \\
\text { failure, aggregation and lipoprotein } \\
\text { separation are not conducive to } \\
\text { downstream analysis }\end{array}$ & $(46)$ \\
\hline $\begin{array}{l}\text { Density gradient } \\
\text { centrifugation }\end{array}$ & $\begin{array}{l}\text { Usually used in combination with the } \\
\text { overspeed centrifuge method }\end{array}$ & Improve the purity of exosomes & $\begin{array}{l}\text { The high viscosity of sucrose solution will } \\
\text { reduce the settling velocity of exosomes } \\
\text { and lead to long time consuming }\end{array}$ & $(47)$ \\
\hline Polymer Precipitatio & $\begin{array}{l}\text { Using the method of virus extraction, } \\
\text { exosomes is obtained by reducing the } \\
\text { solubility of exosomes, usually using } \\
\text { polyethylene glycol (PEG) as medium }\end{array}$ & $\begin{array}{l}\text { Simple operation, short analysis time, } \\
\text { suitable for large-dose sample treatment }\end{array}$ & $\begin{array}{l}\text { Due to its low purity and recovery rate, the } \\
\text { resulting polymer is difficult to remove and } \\
\text { may produce false positive }\end{array}$ & (48) \\
\hline $\begin{array}{l}\text { Size-based isolation } \\
\text { techniques }\end{array}$ & $\begin{array}{l}\text { Based on the size differences between } \\
\text { exosomes and other components of a } \\
\text { biological sample }\end{array}$ & $\begin{array}{l}\text { Fast, simple, low-cost and separated } \\
\text { exosomes have complete structure and } \\
\text { uniform size, and their biological } \\
\text { characteristics will not be significantly } \\
\text { affected. }\end{array}$ & $\begin{array}{l}\text { Other particles of similar size are difficult to } \\
\text { separate, resulting in reduced purity }\end{array}$ & (46) \\
\hline Ultrafiltration & $\begin{array}{l}\text { Ultrafiltration membranes with different } \\
\text { molecular weight cutoffs (MWCO) were } \\
\text { used to selectively separate the samples }\end{array}$ & $\begin{array}{l}\text { The sample cost is low, the concentration } \\
\text { efficiency is high, and the activity of the } \\
\text { exosomes is not affected }\end{array}$ & $\begin{array}{l}\text { Low purity and poor binding of the } \\
\text { exosomes to the ultrafiltration membrane } \\
\text { resulted in low recovery rate. }\end{array}$ & (49) \\
\hline $\begin{array}{l}\text { Immunoaffinity } \\
\text { chromatography } \\
\text { (IAC) }\end{array}$ & $\begin{array}{l}\text { The specificity of antibodies and ligand is } \\
\text { combined to separate the required } \\
\text { exosomes from heterogeneous mixtures }\end{array}$ & $\begin{array}{l}\text { The sample size required is small.It can be } \\
\text { used for the qualitative and quantitative } \\
\text { detection of exosomes. This method has } \\
\text { strong specificity, high sensitivity, high } \\
\text { purity and high yield }\end{array}$ & $\begin{array}{l}\text { The preservation condition of the } \\
\text { exosomes obtained by this method is } \\
\text { harsh, and it is not suitable for large scale } \\
\text { separation of the exosomes. The } \\
\text { non-specific interference adsorption of } \\
\text { matrix produces interfering proteins, which } \\
\text { limits the wide application of this method. }\end{array}$ & (50) \\
\hline
\end{tabular}


validated in multiple animal models (105). For example, mitogen-activated protein kinase kinase kinase (MAP3K) 19 phosphorylates the nucleus of Smad2/3 Translocation and activation of NF- $\kappa B$ reduces lung neutrophil infiltration and BALF levels of KC (a mouse homolog of human IL-8) (106). A recent study has shown that it is caused by infection of the upper respiratory tract. Among the causes of worsening COPD, human rhinovirus (HRV) and non-typeable Hemophilus influenza (NTHI) is the most common. The combined HRV/NTHI response increased IL-17C production, and IL-17C-specific siRNA could block IL-17C and CXCL1 and neutrophil migration induced by HRV/NTHI (107). Trophoblast cells' surface antigen (Trop) 2 expressed on the basal lung compartment's multipotent progenitor cells in preventing COPD airway remodeling Surface antigen. Its specific siRNA reverses cell movement and migration of basal cell hyperplasia. Epithelial-mesenchymal transition (EMT) (108), COPD combined pulmonary hypertension is a common complication of patients, which is closely related to the high expression of the neuron-derived orphan receptor (NOR)1.NOR1 plays a role in regulating inflammation and vascular remodeling. Its specific siRNA inhibits hypoxia-induced cyclin D1 level, cell proliferation, and DNA synthesis in primary human pulmonary artery smooth muscle cells (PASMCs) (109) SI00A4, a secretory member of S100 calcium-binding protein, is highly expressed in COPD patients and mouse models and is involved in the proliferation, migration, and EMT of smooth muscle cells. HIF- $1 \alpha$ or HIF- $2 \alpha$ siRNA can inhibit the high expression of S100A4 (110). Based on the above facts, exosomes play a crucial role in the treatment of COPD. However, COPD is a disease caused by a variety of factors.

\section{FUTURE DIRECTION AND THE LIMITATION}

The study of exosomes vs. COPD is an emerging and rapidly evolving field where we can use exosomes to develop therapeutic tools to prevent and stop lung injury caused by COPD. However, there are still many problems to be solved, such as the lack of uniformity and standardization of exosome detection, isolation,

\section{REFERENCES}

1. Putcha N, Puhan MA, Hansel NN, Drummond MB, Boyd CM. Impact of co-morbidities on self-rated health in self-reported COPD: an analysis of NHANES 2001-2008. COPD. (2013) 10:324-32. doi: $10.3109 / 15412555.2012 .744963$

2. Chen Y, Wang H, Luo G, Dai X. SIRT4 inhibits cigarette smoke extractsinduced mononuclear cell adhesion to human pulmonary microvascular endothelial cells via regulating NF-кB activity. Toxicol Lett. (2014) 226:3207. doi: $10.1016 /$ j.toxlet.2014.02.022

3. Sundar IK, Li D, Rahman I. Small RNA-sequence analysis of plasmaderived extracellular vesicle miRNAs in smokers and patients with chronic obstructive pulmonary disease as circulating biomarkers. J Extracell Vesicles. (2019) 8:1684816. doi: 10.1080/20013078.2019.1684816

4. Salimian J, Mirzaei H, Moridikia A, Harchegani AB, Sahebkar A, Salehi H. Chronic obstructive pulmonary disease: microRNAs and exosomes as new diagnostic and therapeutic biomarkers. J Res Med Sci. (2018) 23:27. doi: 10.4103/jrms.JRMS_1054_17 and purification technologies. The advantages and disadvantages of exosome isolation methods are shown in Table 3. Secondly, the mechanism of exosome uptake by recipient cells is not fully understood. Also, collecting tissue samples from the lungs is more complicated. More in-depth studies are needed to fully understand the pathogenesis of exosomes in COPD and fully reveal the role of miRNA and lncRNA in the disease.

\section{CONCLUSION}

Chronic obstructive pulmonary disease is a heterogeneous disorder marked by airway inflammation, lung tissue damage, and airflow restriction consistent with airway remodeling. Exacerbations are a significant cause of disease development, morbidity, and death, and novel therapies and medications for COPD remain particularly crucial due to a lack of effective drugs. Exosomes are incredibly durable and practical packages of cellular material. They can transfer their bioactive loads to receiver cells across the body, influencing physiological and pathological conditions. Exosomes have considerable clinical value due to their capacity to be controlled and optimized to guide treatment. Although this review tried to highlight the latest evidence of exosomes from various cell sources as biomarkers and their potential for application in COPD treatment, in-depth researches are needed to be used in daily early diagnosis and treatment of COPD.

\section{AUTHOR CONTRIBUTIONS}

NW and QW designed and drafted the manuscript. TD, AG, XW, LS, XL, and KX discussed and revised the manuscript. All authors read and approved the final manuscript.

\section{FUNDING}

This work was supported by the Natural Science Foundation of Shandong Province, China (Grant no. ZR2020MH008).
5. Chen Y, Luo H, Kang N, Guan C, Long Y, Cao J, et al. Beraprost sodium attenuates cigarette smoke extract-induced apoptosis in vascular endothelial cells. Mol Biol Rep. (2012) 39:10447-57. doi: 10.1007/s11033-012-1924-1

6. GBD 2015 Chronic Respiratory Disease Collaborators. Global, regional, and national deaths, prevalence, disability-adjusted life years, and years lived with disability for chronic obstructive pulmonary disease and asthma, 1990-2015: a systematic analysis for the Global Burden of Disease Study 2015. Lancet Respir Med. (2017) 5:691-706. doi: 10.1016/S2213-2600(17) 30293-X

7. GBD 2017 Causes of Death Collaborators. Global, regional, and national agesex-specific mortality for 282 causes of death in 195 countries and territories, 1980-2017: a systematic analysis for the Global Burden of Disease Study 2017. Lancet. (2018) 392:1736-88. doi: 10.1016/S0140-6736(18)32203-7

8. Rabe KF, Watz H. Chronic obstructive pulmonary disease. Lancet. (2017) 389:1931-40. doi: 10.1016/S0140-6736(17)31222-9

9. Pouwels SD, Heijink IH, ten Hacken NH, Vandenabeele P, Krysko DV, Nawijn MC, et al. DAMPs activating innate and adaptive immune responses in COPD. Mucosal Immunol. (2014) 7:215-26. doi: 10.1038/mi.2013.77 
10. Kumar M, Seeger W, Voswinckel R. Senescence-associated secretory phenotype and its possible role in chronic obstructive pulmonary disease. Am J Respir Cell Mol Biol. (2014) 51:323-33. doi: 10.1165/rcmb.2013-0382PS

11. Yao H, Rahman I. Current concepts on oxidative/carbonyl stress, inflammation and epigenetics in pathogenesis of chronic obstructive pulmonary disease. Toxicol Appl Pharmacol. (2011) 254:72-85. doi: 10.1016/j.taap.2009.10.022

12. Gomez-Cabrero D, Menche J, Vargas C, Cano I, Maier D, Barabási AL, et al. From comorbidities of chronic obstructive pulmonary disease to identification of shared molecular mechanisms by data integration. BMC Bioinformatics. (2016) 17(Suppl. 15):441. doi: 10.1186/s12859-016-1291-3

13. Hobbs $\mathrm{BD}$, Hersh $\mathrm{CP}$. Integrative genomics of chronic obstructive pulmonary disease. Biochem Biophys Res Commun. (2014) 452:276-86. doi: 10.1016/j.bbrc.2014.07.086

14. Ezzie ME, Crawford M, Cho JH, Orellana R, Zhang S, Gelinas R, et al. Gene expression networks in COPD: microRNA and mRNA regulation. Thorax. (2012) 67:122-31. doi: 10.1136/thoraxjnl-2011-200089

15. Osei ET, Florez-Sampedro L, Timens W, Postma DS, Heijink IH, Brandsma CA. Unravelling the complexity of COPD by microRNAs: it's a small world after all. Eur Respir J. (2015) 46:807-18. doi: 10.1183/13993003.02139-2014

16. Takahashi T, Kobayashi S, Fujino N, Suzuki T, Ota C, He M, et al. Increased circulating endothelial microparticles in COPD patients: a potential biomarker for COPD exacerbation susceptibility. Thorax. (2012) 67:1067-74. doi: 10.1136/thoraxjnl-2011-201395

17. Njock MS, Cheng HS, Dang LT, Nazari-Jahantigh M, Lau AC, Boudreau E, et al. Endothelial cells suppress monocyte activation through secretion of extracellular vesicles containing antiinflammatory microRNAs. Blood. (2015) 125:3202-12. doi: 10.1182/blood-2014-11-611046

18. Xu H, Ling M, Xue J, Dai X, Sun Q, Chen C, et al. Exosomal microRNA-21 derived from bronchial epithelial cells is involved in aberrant epitheliumfibroblast cross-talk in COPD induced by cigarette smoking. Theranostics. (2018) 8:5419-33. doi: 10.7150/thno.27876

19. Maes T, Cobos FA, Schleich F, Sorbello V, Henket M, De Preter K, et al. Asthma inflammatory phenotypes show differential microRNA expression in sputum. J Allergy Clin Immunol. (2016) 137:1433-46. doi: 10.1016/j.jaci.2016.02.018

20. Lerner CA, Sundar IK, Rahman I. Mitochondrial redox system, dynamics, and dysfunction in lung inflammaging and COPD. Int J Biochem Cell Biol. (2016) 81:294-306. doi: 10.1016/j.biocel.2016.07.026

21. Sundar IK, Yao H, Rahman I. Oxidative stress and chromatin remodeling in chronic obstructive pulmonary disease and smoking-related diseases. Antioxid Redox Signal. (2013) 18:1956-71. doi: 10.1089/ars.2012.4863

22. Porro C, Lepore S, Trotta T, Castellani S, Ratclif L, Battaglino A, et al. Isolation and characterization of microparticles in sputum from cystic fibrosis patients. Respir Res. (2010) 11:94. doi: 10.1186/1465-9921-11-94

23. Caby MP, Lankar D, Vincendeau-Scherrer C, Raposo G, Bonnerot C. Exosomal-like vesicles are present in human blood plasma. Int Immunol. (2005) 17:879-87. doi: 10.1093/intimm/dxh267

24. Ohtani N, Hara E. Roles and mechanisms of cellular senescence in regulation of tissue homeostasis. Cancer Sci. (2013) 104:525-30. doi: 10.1111/cas.12118

25. Admyre C, Grunewald J, Thyberg J, Gripenbäck S, Tornling G, Eklund A, et al. Exosomes with major histocompatibility complex class II and costimulatory molecules are present in human BAL fluid. Eur Respir J. (2003) 22:578-83. doi: 10.1183/09031936.03.00041703

26. van Niel G, D’Angelo G, Raposo G. Shedding light on the cell biology of extracellular vesicles. Nat Rev Mol Cell Biol. (2018) 19:213-28. doi: $10.1038 / \mathrm{nrm} .2017 .125$

27. Cocucci E, Meldolesi J. Ectosomes and exosomes: shedding the confusion between extracellular vesicles. Trends Cell Biol. (2015) 25:364-72. doi: 10.1016/j.tcb.2015.01.004

28. Escola JM, Kleijmeer MJ, Stoorvogel W, Griffith JM, Yoshie O, Geuze HJ. Selective enrichment of tetraspan proteins on the internal vesicles of multivesicular endosomes and on exosomes secreted by human B-lymphocytes. J Biol Chem. (1998) 273:20121-7. doi: 10.1074/jbc.273.32.20121

29. Yoshioka Y, Konishi Y, Kosaka N, Katsuda T, Kato T, Ochiya T. Comparative marker analysis of extracellular vesicles in different human cancer types. $J$ Extracell Vesicles. (2013) 18:2. doi: 10.3402/jev.v2i0.20424
30. Keerthikumar S, Chisanga D, Ariyaratne D, Al Saffar H, Anand S, Zhao K, et al. ExoCarta: a web-based compendium of exosomal cargo. J Mol Biol. (2016) 428:688-92. doi: 10.1016/j.jmb.2015.09.019

31. Pathan M, Fonseka P, Chitti SV, Kang T, Sanwlani R, Van Deun J, et al. Vesiclepedia 2019: a compendium of RNA, proteins, lipids and metabolites in extracellular vesicles. Nucleic Acids Res. (2019) 47:D516-9. doi: 10.1093/nar/gky1029

32. Hough KP, Chanda D, Duncan SR, Thannickal VJ, Deshane JS. Exosomes in immunoregulation of chronic lung diseases. Allergy. (2017) 72:534-44. doi: 10.1111/all.13086

33. Nana-Sinkam SP, Acunzo M, Croce CM, Wang K. Extracellular vesicle biology in the pathogenesis of lung disease. Am J Respir Crit Care Med. (2017) 196:1510-8. doi: 10.1164/rccm.201612-2457PP

34. De Smet EG, Mestdagh P, Vandesompele J, Brusselle GG, Bracke KR. Noncoding RNAs in the pathogenesis of COPD. Thorax. (2015) 70:782-91. doi: 10.1136/thoraxjnl-2014-206560

35. Raposo G, Stoorvogel W. Extracellular vesicles: exosomes, microvesicles, and friends. J Cell Biol. (2013) 200:373-83. doi: 10.1083/jcb.201211138

36. Mathieu M, Martin-Jaular L, Lavieu G, Théry C. Specificities of secretion and uptake of exosomes and other extracellular vesicles for cell-to-cell communication. Nat Cell Biol. (2019) 21:9-17. doi: 10.1038/s41556-018-0250-9

37. Kalluri R, LeBleu VS. The biology, function, and biomedical applications of exosomes. Science. (2020) 367:eaau6977. doi: 10.1126/science.aau6977

38. Kubo H. Extracellular vesicles in lung disease. Chest. (2018) 153:210-6. doi: 10.1016/j.chest.2017.06.026

39. Fujita Y, Kosaka N, Araya J, Kuwano K, Ochiya T. Extracellular vesicles in lung microenvironment and pathogenesis. Trends Mol Med. (2015) 21:53342. doi: 10.1016/j.molmed.2015.07.004

40. Simpson RJ, Jensen SS, Lim JW. Proteomic profiling of exosomes: current perspectives. Proteomics. (2008) 8:4083-99. doi: 10.1002/pmic.200800109

41. Wahlund CJE, Eklund A, Grunewald J, Gabrielsson S. Pulmonary extracellular vesicles as mediators of local and systemic inflammation. Front Cell Dev Biol. (2017) 5:39. doi: 10.3389/fcell.2017.00039

42. Van Pottelberge GR, Mestdagh P, Bracke KR, Thas O, van Durme YM, Joos GF, et al. MicroRNA expression in induced sputum of smokers and patients with chronic obstructive pulmonary disease. Am J Respir Crit Care Med. (2011) 183:898-906. doi: 10.1164/rccm.201002-0304OC

43. Molina-Pinelo S, Pastor MD, Suarez R, Romero-Romero B, González De la Peña M, Salinas A, et al. MicroRNA clusters: dysregulation in lung adenocarcinoma and COPD. Eur Respir J. (2014) 43:1740-9. doi: 10.1183/09031936.00091513

44. Cao Z, Zhang N, Lou T, Jin Y, Wu Y, Ye Z, et al. MicroRNA-183 downregulates the expression of $\mathrm{BKCa} \beta 1$ protein that is related to the severity of chronic obstructive pulmonary disease. Hippokratia. (2014) 18:328-32.

45. Donaldson A, Natanek SA, Lewis A, Man WD, Hopkinson NS, Polkey MI, et al. Increased skeletal muscle-specific microRNA in the blood of patients with COPD. Thorax. (2013) 68:1140-9. doi: 10.1136/thoraxjnl-2012-203129

46. Savarimuthu Francis SM, Davidson MR, Tan ME, Wright CM, Clarke BE, Duhig EE, et al. MicroRNA-34c is associated with emphysema severity and modulates SERPINE1 expression. BMC Genomics. (2014) 15:88. doi: 10.1186/1471-2164-15-88

47. Gelb AF, Hogg JC, Müller NL, Schein MJ, Kuei J, Tashkin DP, et al. Contribution of emphysema and small airways in COPD. Chest. 1996;109(2):353-9. doi: 10.1378/chest.109.2.353

48. Grimson A, Farh KK, Johnston WK, Garrett-Engele P, Lim LP, Bartel DP. MicroRNA targeting specificity in mammals: determinants beyond seed pairing. Mol Cell. (2007) 27:91-105. doi: 10.1016/j.molcel.2007.06.017

49. Halappanavar S, Nikota J, Wu D, Williams A, Yauk CL, Stampfli M. IL1 receptor regulates microRNA-135b expression in a negative feedback mechanism during cigarette smoke-induced inflammation. J Immunol. (2013) 190:3679-86. doi: 10.4049/jimmunol.1202456

50. Mizuno S, Bogaard HJ, Gomez-Arroyo J, Alhussaini A, Kraskauskas D, Cool CD, et al. MicroRNA-199a-5p is associated with hypoxia-inducible factor$1 \alpha$ expression in lungs from patients with COPD. Chest. (2012) 142:663-72. doi: 10.1378/chest.11-2746

51. Schembri F, Sridhar S, Perdomo C, Gustafson AM, Zhang X, Ergun A, et al. MicroRNAs as modulators of smoking-induced gene expression changes in 
human airway epithelium. Proc Natl Acad Sci USA. (2009) 106:2319-24. doi: 10.1073/pnas.0806383106

52. Xie L, Wu M, Lin H, Liu C, Yang H, Zhan J, et al. An increased ratio of serum miR-21 to miR-181a levels is associated with the early pathogenic process of chronic obstructive pulmonary disease in asymptomatic heavy smokers. Mol Biosyst. (2014) 10:1072-81. doi: 10.1039/C3MB70564A

53. Gu C, Li Y, Liu J, Ying X, Liu Y, Yan J, et al. LncRNA-mediated SIRT1/FoxO3a and SIRT1/p53 signaling pathways regulate type II alveolar epithelial cell senescence in patients with chronic obstructive pulmonary disease. Mol Med Rep. (2017) 15:3129-34. doi: 10.3892/mmr.2017.6367

54. Tang W, Shen Z, Guo J, Sun S. Screening of long non-coding RNA and TUG1 inhibits proliferation with TGF- $\beta$ induction in patients with COPD. Int J Chron Obstruct Pulmon Dis. (2016) 11:2951-64. doi: $10.2147 / C O P D . S 109570$

55. Bi H, Zhou J, Wu D, Gao W, Li L, Yu L, et al. Microarray analysis of long non-coding RNAs in COPD lung tissue. Inflamm Res. (2015) 64:119-26. doi: 10.1007/s00011-014-0790-9

56. Poulet C, Njock MS, Moermans C, Louis E, Louis R, Malaise M, et al. Exosomal long non-coding RNAs in lung diseases. Int J Mol Sci. (2020) 21:3580 doi: $10.3390 /$ ijms 21103580

57. Cordazzo C, Petrini S, Neri T, Lombardi S, Carmazzi Y, Pedrinelli R, et al. Rapid shedding of proinflammatory microparticles by human mononuclear cells exposed to cigarette smoke is dependent on $\mathrm{Ca} 2+$ mobilization. Inflamm Res. (2014) 63:539-47. doi: 10.1007/s00011-014-0723-7

58. Tan DBA, Armitage J, Teo TH, Ong NE, Shin H, Moodley YP. Elevated levels of circulating exosome in COPD patients are associated with systemic inflammation. Respir Med. (2017) 132:261-4. doi: 10.1016/j.rmed.2017.04.014

59. Moon HG, Kim SH, Gao J, Quan T, Qin Z, Osorio JC, et al. CCN1 secretion and cleavage regulate the lung epithelial cell functions after cigarette smoke. Am J Physiol Lung Cell Mol Physiol. (2014) 307:L326-37. doi: 10.1152/ajplung.00102.2014

60. Kanazawa H, Yoshikawa J. Elevated oxidative stress and reciprocal reduction of vascular endothelial growth factor levels with severity of COPD. Chest. (2005) 128:3191-7. doi: 10.1378/chest.128.5.3191

61. Stockley RA, Turner AM. $\alpha$-1-Antitrypsin deficiency: clinical variability, assessment, and treatment. Trends Mol Med. (2014) 20:105-15. doi: 10.1016/j.molmed.2013.11.006

62. Disayabutr S, Kim EK, Cha SI, Green G, Naikawadi RP, Jones KD, et al. miR34 miRNAs regulate cellular senescence in type II alveolar epithelial cells of patients with idiopathic pulmonary fibrosis. PLoS ONE. (2016) 11:e0158367. doi: 10.1371/journal.pone.0158367

63. Fujita Y, Araya J, Ito S, Kobayashi K, Kosaka N, Yoshioka Y, et al. Suppression of autophagy by extracellular vesicles promotes myofibroblast differentiation in COPD pathogenesis. J Extracell Vesicles. (2015) 4:28388. doi: $10.3402 /$ jev.v4.28388

64. Shen W, Liu J, Fan M, Wang S, Zhang Y, Wen L, et al. MiR-3202 protects smokers from chronic obstructive pulmonary disease through inhibiting FAIM2: an in vivo and in vitro study. Exp Cell Res. (2018) 362:370-7. doi: 10.1016/j.yexcr.2017.11.038

65. Conickx G, Mestdagh P, Avila Cobos F, Verhamme FM, Maes T, Vanaudenaerde BM, et al. MicroRNA profiling reveals a role for microRNA218-5p in the pathogenesis of chronic obstructive pulmonary disease. Am J Respir Crit Care Med. (2017) 195:43-56. doi: 10.1164/rccm.201506-1182OC

66. Lewis A, Riddoch-Contreras J, Natanek SA, Donaldson A, Man WD, Moxham J, et al. Downregulation of the serum response factor/miR-1 axis in the quadriceps of patients with COPD. Thorax. (2012) 67:26-34. doi: 10.1136/thoraxjnl-2011-200309

67. Gu W, Yuan Y, Wang L, Yang H, Li S, Tang Z, et al. Long non-coding RNA TUG1 promotes airway remodelling by suppressing the miR-145-5p/DUSP6 axis in cigarette smoke-induced COPD. J Cell Mol Med. (2019) 23:7200-9. doi: $10.1111 / \mathrm{jcmm} .14389$

68. Ge J, Geng S, Jiang H. Long noncoding RNAs antisense noncoding RNA in the INK4 locus (ANRIL) correlates with lower acute exacerbation risk, decreased inflammatory cytokines, and mild GOLD stage in patients with chronic obstructive pulmonary disease. J Clin Lab Anal. (2019) 33:e22678. doi: $10.1002 /$ jcla. 22678
69. Buschow SI, van Balkom BW, Aalberts M, Heck AJ, Wauben M, Stoorvogel W. MHC class II-associated proteins in B-cell exosomes and potential functional implications for exosome biogenesis. Immunol Cell Biol. (2010) 88:851-6. doi: 10.1038/icb.2010.64

70. Barnes PJ. Immunology of asthma and chronic obstructive pulmonary disease. Nat Rev Immunol. (2008) 8:183-92. doi: 10.1038/nri2254

71. Mittelbrunn M, Sánchez-Madrid F. Intercellular communication: diverse structures for exchange of genetic information. Nat Rev Mol Cell Biol. (2012) 13:328-35. doi: 10.1038/nrm3335

72. Sobo-Vujanovic A, Munich S, Vujanovic NL. Dendritic-cell exosomes crosspresent Toll-like receptor-ligands and activate bystander dendritic cells. Cell Immunol. (2014) 289:119-27. doi: 10.1016/j.cellimm.2014.03.016

73. Lunding L, Wegmann M. NK cells in asthma exacerbation. Oncotarget. (2015) 6:19932-3. doi: 10.18632/oncotarget.4841

74. Zhang B, Yin Y, Lai RC, Lim SK. Immunotherapeutic potential of extracellular vesicles. Front Immunol. (2014) 5:518. doi: 10.3389/fimmu.2014.00518

75. Wang Y, Xu J, Meng Y, Adcock IM, Yao X. Role of inflammatory cells in airway remodeling in COPD. Int J Chron Obstruct Pulmon Dis. (2018) 13:3341-8. doi: 10.2147/COPD.S176122

76. Lefkowitz DL, Lefkowitz SS. Macrophage-neutrophil interaction: a paradigm for chronic inflammation revisited. Immunol Cell Biol. (2001) 79:502-6. doi: 10.1046/j.1440-1711.2001.01020.x

77. Ismail N, Wang Y, Dakhlallah D, Moldovan L, Agarwal K, Batte K, et al. Macrophage microvesicles induce macrophage differentiation and miR-223 transfer. Blood. (2013) 121:984-95. doi: 10.1182/blood-2011-08-374793

78. Lee H, Zhang D, Wu J, Otterbein LE, Jin Y. Lung epithelial cellderived microvesicles regulate macrophage migration via microRNA17/221-induced integrin $\beta(1)$ recycling. J Immunol. (2017) 199:1453-64. doi: 10.4049/jimmunol.1700165

79. Lee H, Zhang D, Zhu Z, Dela Cruz CS, Jin Y. Epithelial cell-derived microvesicles activate macrophages and promote inflammation via microvesicle-containing microRNAs. Sci Rep. (2016) 6:35250. doi: $10.1038 /$ srep 35250

80. Serban KA, Rezania S, Petrusca DN, Poirier C, Cao D, Justice MJ, et al. Structural and functional characterization of endothelial microparticles released by cigarette smoke. Sci Rep. (2016) 6:31596. doi: 10.1038/srep31596

81. Yáñez-Mó M, Siljander PR, Andreu Z, Zavec AB, Borràs FE, Buzas EI, et al. Biological properties of extracellular vesicles and their physiological functions. J Extracell Vesicles. (2015) 4:27066. doi: 10.3402/jev.v4.27066

82. Kulshreshtha A, Ahmad T, Agrawal A, Ghosh B. Proinflammatory role of epithelial cell-derived exosomes in allergic airway inflammation. J Allergy Clin Immunol. (2013) 131:1194-203, 203.e1-14. doi: 10.1016/j.jaci.2012.12.1565

83. Li N, Liu Y, Cai J. LncRNA MIR155HG regulates M1/M2 macrophage polarization in chronic obstructive pulmonary disease. Biomed Pharmacother. (2019) 117:109015. doi: 10.1016/j.biopha.2019.109015

84. Van Eeden SF, Hogg JC. Immune-modulation in chronic obstructive pulmonary disease: current concepts and future strategies. Respiration. (2020) 99:550-65. doi: 10.1159/000502261

85. Genschmer KR, Russell DW, Lal C, Szul T, Bratcher PE, Noerager BD, et al. Activated PMN exosomes: pathogenic entities causing matrix destruction and disease in the lung. Cell. (2019) 176:113-26.e15. doi: 10.1016/j.cell.2018.12.002

86. Laurell CB, Eriksson S. The electrophoretic $\alpha 1$-globulin pattern of serum in $\alpha 1$-antitrypsin deficiency. 1963. COPD. (2013) 10(Suppl. 1):3-8. doi: 10.3109/15412555.2013.771956

87. Sng JJ, Prazakova S, Thomas PS, Herbert C. MMP-8, MMP-9 and neutrophil elastase in peripheral blood and exhaled breath condensate in COPD. COPD. (2017) 14:238-44. doi: 10.1080/15412555.2016.1249790

88. Senior RM, Tegner H, Kuhn C, Ohlsson K, Starcher BC, Pierce JA. The induction of pulmonary emphysema with human leukocyte elastase. Am Rev Respir Dis. (1977) 116:469-75. doi: 10.1164/arrd.1977.116.3.469

89. Veerappan A, Thompson M, Savage AR, Silverman ML, Chan WS, Sung B, et al. Mast cells and exosomes in hyperoxia-induced neonatal lung disease. Am J Physiol Lung Cell Mol Physiol. (2016) 310:L1218-32. doi: 10.1152/ajplung.00299.2015 
90. Wen C, Seeger RC, Fabbri M, Wang L, Wayne AS, Jong AY. Biological roles and potential applications of immune cell-derived extracellular vesicles. $J$ Extracell Vesicles. (2017) 6:1400370. doi: 10.1080/20013078.2017.1400370

91. Qazi KR, Gehrmann U, Domange Jordö E, Karlsson MC, Gabrielsson S. Antigen-loaded exosomes alone induce Thl-type memory through a B-cell-dependent mechanism. Blood. (2009) 113:2673-83. doi: 10.1182/blood-2008-04-153536

92. Julich H, Willms A, Lukacs-Kornek V, Kornek M. Extracellular vesicle profiling and their use as potential disease specific biomarker. Front Immunol. (2014) 5:413. doi: 10.3389/fimmu.2014.00413

93. Kornek M, Lynch M, Mehta SH, Lai M, Exley M, Afdhal NH, et al. Circulating microparticles as disease-specific biomarkers of severity of inflammation in patients with hepatitis $\mathrm{C}$ or nonalcoholic steatohepatitis. Gastroenterology. (2012) 143:448-58. doi: 10.1053/j.gastro.2012.04.031

94. Lacedonia D, Carpagnano GE, Trotta T, Palladino GP, Panaro MA, Zoppo LD, et al. Microparticles in sputum of COPD patients: a potential biomarker of the disease? Int J Chron Obstruct Pulmon Dis. (2016) 11:527-33. doi: $10.2147 /$ COPD.S99547

95. Shi L, Xin Q, Chai R, Liu L, Ma Z. Ectopic expressed miR-203 contributes to chronic obstructive pulmonary disease via targeting TAK1 and PIK3CA. Int J Clin Exp Pathol. (2015) 8:10662-70.

96. Wang R, Li M, Zhou S, Zeng D, Xu X, Xu R, et al. Effect of a single nucleotide polymorphism in miR-146a on COX-2 protein expression and lung function in smokers with chronic obstructive pulmonary disease. Int J Chron Obstruct Pulmon Dis. (2015) 10:463-73. doi: 10.2147/COPD.S74345

97. Kara M, Kirkil G, Kalemci S. Differential expression of microRNAs in chronic obstructive pulmonary disease. Adv Clin Exp Med. (2016) 25:21-6. doi: $10.17219 /$ acem $/ 28343$

98. Devadoss D, Long C, Langley RJ, Manevski M, Nair M, Campos MA, et al. Long noncoding transcriptome in chronic obstructive pulmonary disease. Am J Respir Cell Mol Biol. (2019) 61:678-88. doi: 10.1165/rcmb.2019-0184TR

99. Lewis A, Lee JY, Donaldson AV, Natanek SA, Vaidyanathan S, Man WD, et al. Increased expression of H19/miR-675 is associated with a low fat-free mass index in patients with COPD. J Cachexia Sarcopenia Muscle. (2016) 7:330-44. doi: $10.1002 /$ jcsm. 12078

100. Mei D, Tan WSD, Tay Y, Mukhopadhyay A, Wong WSF. Therapeutic RNA strategies for chronic obstructive pulmonary disease. Trends Pharmacol Sci. (2020) 41:475-86. doi: 10.1016/j.tips.2020.04.007

101. Sun Y, An N, Li J, Xia J, Tian Y, Zhao P, et al. miRNA-206 regulates human pulmonary microvascular endothelial cell apoptosis via targeting in chronic obstructive pulmonary disease. J Cell Biochem. (2019) 120:6223-36. doi: $10.1002 /$ jcb. 27910

102. Sørheim IC, Johannessen A, Gulsvik A, Bakke PS, Silverman EK, DeMeo DL. Gender differences in COPD: are women more susceptible to smoking effects than men? Thorax. (2010) 65:480-5. doi: 10.1136/thx.2009.122002
103. Du Y, Ding Y, Chen X, Mei Z, Ding H, Wu Y, et al. MicroRNA181c inhibits cigarette smoke-induced chronic obstructive pulmonary disease by regulating CCN1 expression. Respir Res. (2017) 18:155. doi: 10.1186/s12931-017-0639-1

104. Paschalaki KE, Zampetaki A, Baker JR, Birrell MA, Starke RD, Belvisi MG, et al. Downregulation of microRNA-126 augments DNA damage response in cigarette smokers and patients with chronic obstructive pulmonary disease. Am J Respir Crit Care Med. (2018) 197:665-8. doi: 10.1164/rccm.201706-1304LE

105. Dua K, Wadhwa R, Singhvi G, Rapalli V, Shukla SD, Shastri MD, et al. The potential of siRNA based drug delivery in respiratory disorders: recent advances and progress. Drug Dev Res. (2019) 80:714-30. doi: $10.1002 / \mathrm{ddr} .21571$

106. Boehme SA, Franz-Bacon K, Ludka J, DiTirro DN, Ly TW, Bacon KB. MAP3K19 is overexpressed in COPD and is a central mediator of cigarette smoke-induced pulmonary inflammation and lower airway destruction. PLoS ONE. (2016) 11:e0167169. doi: 10.1371/journal.pone.0167169

107. Jamieson KC, Traves SL, Kooi C, Wiehler S, Dumonceaux CJ, Maciejewski $\mathrm{BA}$, et al. Rhinovirus and bacteria synergistically induce IL-17C release from human airway epithelial cells to promote neutrophil recruitment. J Immunol. (2019) 202:160-70. doi: 10.4049/jimmunol.1800547

108. Liu Q, Li H, Wang Q, Zhang Y, Wang W, Dou S, et al. Increased expression of TROP2 in airway basal cells potentially contributes to airway remodeling in chronic obstructive pulmonary disease. Respir Res. (2016) 17:159. doi: 10.1186/s12931-016-0463-z

109. Wang CG, Li C, Lei W, Jiang JH, Huang JA, Zeng DX. The association of neuron-derived orphan receptor 1 with pulmonary vascular remodeling in COPD patients. Int J Chron Obstruct Pulmon Dis. (2018) 13:1177-86. doi: 10.2147/COPD.S151820

110. Reimann S, Fink L, Wilhelm J, Hoffmann J, Bednorz M, Seimetz M, et al. Increased S100A4 expression in the vasculature of human COPD lungs and murine model of smoke-induced emphysema. Respir Res. (2015) 16:127. doi: $10.1186 / \mathrm{s} 12931-015-0284-5$

Conflict of Interest: The authors declare that the research was conducted in the absence of any commercial or financial relationships that could be construed as a potential conflict of interest.

Copyright (c) 2021 Wang, Wang, Du, Gabriel, Wang, Sun, Li, Xu, Jiang and Zhang. This is an open-access article distributed under the terms of the Creative Commons Attribution License (CC BY). The use, distribution or reproduction in other forums is permitted, provided the original author(s) and the copyright owner(s) are credited and that the original publication in this journal is cited, in accordance with accepted academic practice. No use, distribution or reproduction is permitted which does not comply with these terms. 